\section{MRS COUNCIL MEETING}

A meeting of the MRS Council was hosted by K. N. Tu at IBM Research, Yorktown Heights, N. Y., on Wednesday, March 19. Many issues were discussed and the following substantive motions were adopted:

1) The Society has signed an agreement with Elsevier-North Holland to publish MRS proceedings under a unified format. At least three of this year's symposia will be published as separate volumes under MRS sponsorship. The Society anticipates that this series will be an important addition to the Materials Science literature.

2) A committee was formed to enlist more corporate sponsorship to insure that the Society's finances rest on a sound foundation. R. J. H. Voorhoeve (Celanese Cor.) will chair the committee and E. N. Kaufmann Bell Labs) will be Vice-Chairman.

3) A student award program was adopted. (See related article, p. 5).

The Council discussed at length cooperation with the American Physical Society (APS). (See related article which follows.) In general, while the Council was enthusiastic about ties with the APS, an APS proposal to run a joint MRS-APS meeting on the East Coast in 1981 was not adopted. It was felt that the Society would lose some of its identity in a large joint meeting. However it was felt that there were obvious benefit to sponsoring individual joint symposia, and the APS-MRS will run a joint symposium in 1981 on IonImplantation.

\section{COOPERATION BETWEEN MATERI- ALS RESEARCH SOCIETY AND AMERICAN PHYSICAL SOCIETY}

On January 11, 1978 discussions were held between representatives of the Materials Research Society (J. M. Poate, K. A. Jackson and R. J. H. Voorhoeve) and the
Committee on Applications of Physics of APS (CAP). The purpose of the meeting was to explore ways in which the two Societies can cooperate in their efforts to serve those of us who apply physics in the characterization, processing and application of materials. Since the Materials Research Society serves a wide spectrum of scientists with backgrounds in a large number of different disciplines, it is useful to weave collaborative patterns with disciplineoriented societies such as APS.

At the meeting, it was agreed that we should strive towards coordination of topical meetings and mutual assistance in organizing the best possible forums for materials science. The CAP unit of APS recognizes that recent MRS meetings have been highly successful and illustrative of the type of meetings in which they believe many physicists would like to participate.

Concrete steps towards cooperation and coordination include a symposium on ion-implantation scheduled for the 1981 MRS meeting in Boston, to be co-sponsored by the CAP group of APS. Also, announcements of topical symposia to be held at the 1980 MRS meeting in Boston will be published in the APS Bulletin.

\section{MATERIALS RESEARCH SOCIETY ANNUAL MEETING AWARDS FOR GRADUATE STUDENTS}

The Materials Research Society announces the availability of ten awards for graduate students conducting research on a topic to be addressed in the several symposia planned for the 1980 annual meeting. Each award will consist of a cash grant of $\$ 50$, to be presented at the Von Hippel Award ceremony during the meeting, a waiver of the registration fee, and a travel grant amounting ton one-half the price of economy round-trip air fare from the student's community to Boston, MA, the site of the 1980 meeting.

Criteria for selection are: 